\title{
DEVELOPMENT OF EDUCATIONAL TOURISM IN LITHUANIAN RURAL AREAS
}

\author{
Jurgita Zaleckienė, Laura Turčinskaitė \\ Vytautas Magnus University Agriculture Academy, Lithuania \\ jurgita.zaleckiene@vdu.lt
}

\begin{abstract}
Tourism development contributes to the vitality of rural areas: it increases employment opportunities for residents, promotes the development of relations among different business entities and attractiveness of rural environment. In this article, the situation regarding the development of one type of tourism - educational tourism - in Lithuanian rural areas, factors encouraging and limiting this development have been analyzed. The research question is what are the main problems regarding the development of educational tourism in rural areas. The aim of the research is to present relevant solutions after the analysis of the problems regarding the development of educational tourism in rural areas. Theoretical research was performed while applying methods of content analysis and synthesis of scientific literature and other researches. The method of case analysis was chosen to describe the state of the development of educational tourism and to identify main problems. In total 18 cases were analyzed (18 providers of the educational tourism services in rural areas). In order to collect necessary information, methods of semi-structured interview, analysis of secondary informational resources and direct participation in researched educational programs were applied. The development of educational tourism is promoted by the factors related to the environment of manor, historical place or nature as well as professional qualification, working experience, enthusiasm and ability to be flexible about customers' needs of actors responsible for rural development. Volatility of demand regarding educational programs, lack of specialists and challenges related to cooperation were identified as problematic issues.
\end{abstract}

Key words: education, educational tourism, rural area, types of tourism.

\section{Introduction}

The decline of the importance of agriculture as well as problems regarding population of residents, infrastructure and employment in rural areas (Kuliešis \& Pareigiené, 2014), encouraged academics and practitioners to search possible solutions related to maintenance of the vitality of rural areas while ensuring sustainable territorial development.

Researchers (Wang \& Yotsumoto, 2018; Atkočiunniené, 2011) follow the opinion that the development of tourism (or tourism products) has a positive effect towards the local, regional and national economy, society, culture and environment. The development of tourism can improve regional economy, for example, industry, employment, cooperation among business entities (Hermawan et al., 2018). The benefit of tourism development towards rural development is scientifically based; however, dynamic environment causes the constant need to analyze situation, threats and opportunities for the development of tourism.

In scientific researches (Astromskienè, 2009; Atkočiūnienè, 2011; Wang \& Yotsumoto, 2018), academics analyze the development of rural tourism; however, there are various types of tourism. In this article, the situation regarding the development of one type of tourism - educational tourism has been analyzed. To define educational tourism as a separate type of tourism is quite difficult, because it includes various elements of cultural, cognitive and countryside tourism (Richards \& Wilson, 2007); however, a distinctive feature of educational tourism - the main (or secondary) priority - is learning process in a unique environment. While providing/using the services of educational tourism, the immediate interaction takes place between two interested parties: participants and organizers of education (Sie, Patterson, \& Pegg, 2016). The organizers can be local communities, farmers, countryside tourism homesteads, museums, cultural centers (Sie, Patterson, \& Pegg, 2016). Favorable conditions for the development of educational tourism exist in the rural area. Firstly, due to globalization and scientific and technological progress, the supply of educational tourism services grows, life cycle of tourism services is becoming shorter; however, in rural areas the situation is different - here the duration of tourism services is limited. Thus, the development of different types of tourism would cause a growth of supply. Secondary, tourists' purposes and motives are changing (Baležentis \& Žuromskaite, 2012; Carneiro, Lima, \& Silva, 2015; Petroman et al., 2016). More and more often consumers prioritize learning about culture, local traditions and customs of the visited place. They appreciate an opportunity to try/create/ learn/find out by themselves. Natural, not polluted environment makes this type of tourism even more attractive. Thirdly, the development of several related types of tourism, combination of agricultural business and tourism activities can encourage a synergy between different types of activities, for instance, development of educational tourism can reduce seasonality of rural tourism. The effect of synergy in different types of farm activities can be created by so-called 'conformity with the market', i.e. products of different activities (agricultural activities and other) are consumed by the same consumers, for example, products of beekeeping, horticulture are used in the educational programs. Also, the interest in lifelong learning has increased 
as well (Carneiro, Lima, \& Silva, 2015; Lane \& Kastenholz, 2015). Finally, promotion of vitality of rural areas is one of the priorities not only among local inhabitants, but representatives of government as well. As a result, business development in rural areas is promoted by financial instruments. Scholars (Richards \& Wilson, 2007) point out that the demand for services of educational tourism has been growing in rural areas recently, because it is an effective way to represent history, culture, traditions, wisdom of the elders; also, it increases the supply of educational services.

Thus, it is relevant to analyze how other types of tourism contribute to the development of rural areas and what kind of challenges are faced. Researches (Astromskienè, 2009; Pilipavičius, 2011) identify several problematic issues regarding development of rural business (not only rural tourism): weak cooperation, lack of professionalism and initiative, limited abilities to develop business in changing environment. On the other hand, the market of rural business is small. Rural business entities are not able to produce everything - this area is producing minor part of goods (Zaleckienè, 2015). The research question is what are the problems related to the development of educational tourism in rural areas. The aim of the article is to present possible solutions after the analysis of the problems regarding the development of educational tourism in rural areas.

\section{Materials and Methods}

Educational programs - one of the most important subjects of the educational tourism - were analyzed in order to perform an analysis of the development of educational tourism in Lithuanian rural areas ${ }^{1}$. Criteria and subcriteria of research object are summarized in Table 1.

In order to perform a detailed analysis of the development of educational tourism in Lithuania, case analyses were carried out (Table 2). Principles of recognition/popularity and accessibility for search were applied in empirical research related to the case analyses. Manors of Zypliai, Kiduliai and Gelgaudiškis were chosen due to wide range of suggested educational programs. Raudondvaris manor was chosen due to wide range of educational programs regarding handicrafts. Regional parks of Panemuniai, Nemunas loops and Tytuvenai were chosen due to wide range of educational programs regarding nature.

In order to gather necessary information, different methods were applied: 1) semi-structured interview. This research method was used to gather necessary information regarding particular educational programs (how long they are performed, who choses topics, what type of problems occur while organizing educational programs, who the main participants of educational programs are, cooperation relations and etc.). During semi-structured interview 8 respondents (guides, representatives of communities, countryside tourism

Table 1

\section{Criteria and subcriteria of analysis of educational tourism in Lithuania (compiled by the authors)}

\begin{tabular}{|c|c|c|}
\hline Criteria & Subcriteria & Detail \\
\hline $\begin{array}{l}\text { Educational } \\
\text { objects }\end{array}$ & $\begin{array}{l}\text { Gastronomy } \\
\text { Handicrafts } \\
\text { Wildlife } \\
\text { Historical (architecture, old articles, famous people, historical places) } \\
\text { Cultural (tales, theater, dances) } \\
\text { Festive } \\
\text { Sports }\end{array}$ & $\begin{array}{l}\text { Subjects were selected in } \\
\text { accordance with L. Sie, I. } \\
\text { Patterson \& S. Pegg (2016) }\end{array}$ \\
\hline Organizers & $\begin{array}{l}\text { Manors } \\
\text { Rural communities } \\
\text { Countryside tourism homestead } \\
\text { Regional parks }\end{array}$ & \multirow{3}{*}{$\begin{array}{l}\text { Cases of rural communities } \\
\text { and countryside tourism } \\
\text { homesteads were chosen } \\
\text { while following the principle } \\
\text { of accessibility - key words } \\
\text { 'educational programs of rura } \\
\text { communities', 'educational } \\
\text { programs of countryside } \\
\text { tourism homesteads' were } \\
\text { typed into Google web search } \\
\text { engine (www.google.lt). }\end{array}$} \\
\hline Seasonality & $\begin{array}{l}\text { Full-year } \\
\text { Certain months } \\
\text { Seasons }\end{array}$ & \\
\hline Participants & $\begin{array}{l}\text { All } \\
\text { Children } \\
\text { Adults } \\
\text { Pupils } \\
\text { Families } \\
\text { Foreigners }\end{array}$ & \\
\hline
\end{tabular}

Rural area - a residential place of small number of inhabitants predominated by natural environment, landscape; the main activity of local inhabitants - agriculture (Pilipavičius, 2011). 
Chosen cases (compiled by the authors) $(\mathrm{N}=18)$

\begin{tabular}{|l|l|}
\hline \multicolumn{1}{|c|}{ Educational tourism programs providers } & \multicolumn{1}{c|}{ Cases } \\
\hline Manors & Zypliai, Kiduliai, Gelgaudiškis and Raudondvaris (N=4) \\
\hline Rural communities & $\begin{array}{l}\text { Adomyné, Gižai, Lekéčiai, Virbalys, Biliūnai, Žiobiškis and } \\
\text { Junkilai }(\mathrm{N}=7)\end{array}$ \\
\hline Countryside tourism homesteads & Dalgedai, Šušve், Širvynė and Grikucis $(\mathrm{N}=4)$ \\
\hline Regional parks & Panemuniai, Tytuvėnai ir Nemunas loops $(\mathrm{N}=3)$ \\
\hline
\end{tabular}

homesteads, educators) were interviewed. Another method that was used: 2) analysis of secondary informational sources. Websites of chosen cases were considered as secondary informational sources. While applying this method, the information regarding the object, duration, price, number of participants, time of the chosen cases were gathered; Also, we used: 3) research while participating. In order to collect necessary information for empirical research, it was decided to participate in educational program and to communicate with organize and managers of educational programs.

The chosen research methods complement each other and help to solve the issue of the lack of information regarding the organization of educational programs, relations with other objects of rural development and etc.

Empirical research was carried out during the period from July to December in 2018.

\section{Results and Discussion}

The analysis of the cases showed that educational tourism has been developed in rural areas. Due to the lack of information, it is difficult to describe tendencies; however, the structural interview has shown that the majority of educational programs has been implemented more than one year (five years or more). Despite the fact that educational programs related to specific activities (businesses/handicrafts) predominate, the grouping of suggested programs suggests that programs offered in rural areas are quite diverse (Figure 1).

Structured interview with the suppliers of educational programs highlighted that topics of educational programs are related to environment (environment of manor, historical places, events), natural resources (flora and fauna), seasons, calendar of folk and religious celebrations.

The greatest variety and number of educational programs was identified in manors $(7-10$ educational programs in one manor). This is caused by the fact that there are enough resources in manors, for example, premises. In addition, manors are already attractive tourism destinations - the number of visitors is higher there. On the other hand, specialists who work in manors and educational programs are included in tourism routes. Organization and development of educational programs are more organized in comparison with other suppliers of educational programs, for instance, countryside tourism homesteads or rural communities.

Meanwhile rural communities, countryside tourism homestead offer limited number of educational programs (mainly one per day) due to limited resources (material, human). The variety of educational programs is also quite small: in rural communities 1-2 educational programs are offered, in countryside tourism homestead - from 1 to 7 . The most popular educational programs in these objects

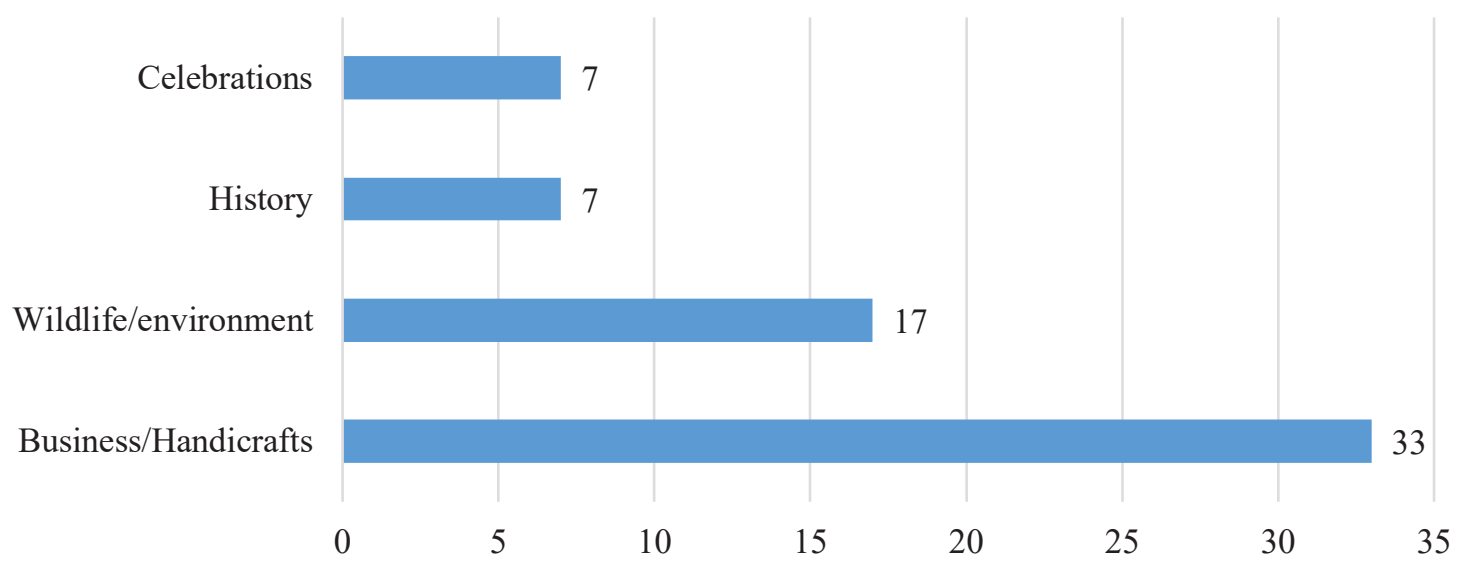

Figure 1. Division of educational programs according to the objects, units $(\mathrm{N}=18)$. 


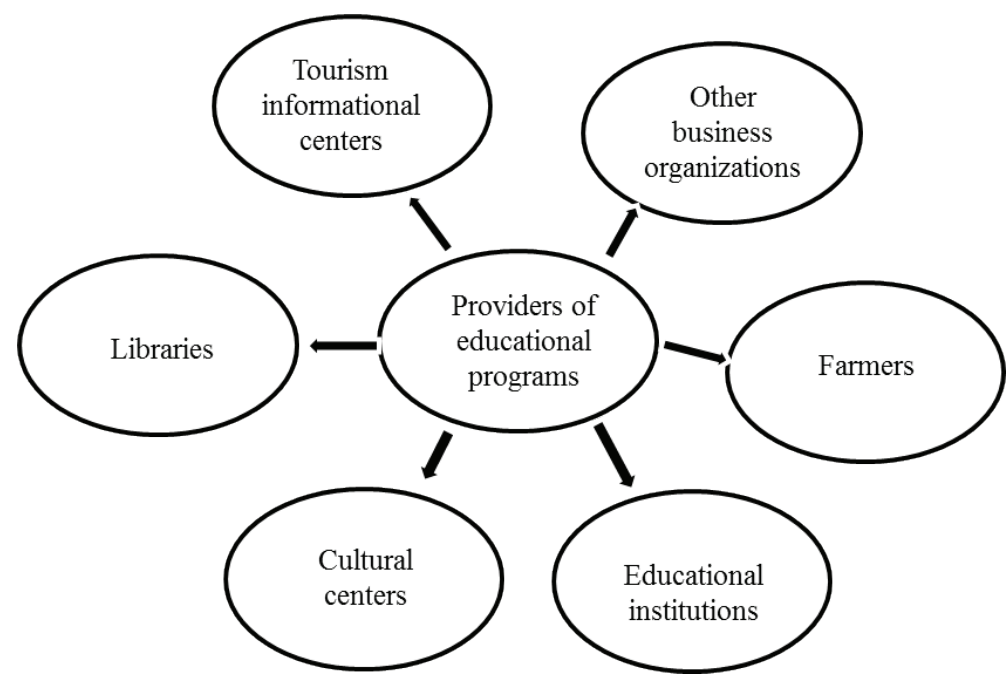

Figure 2. Involvement of other participants in development of educational tourism.

are gastronomical programs while the premises and tools are available.

In most researched cases educational programs have been implemented throughout the year except regional parks, where a distinctive feature is dependence on seasons (spring - summer - autumn). Educational programs in nature are not very popular in cold season. Representatives of rural communities also noted that not all educational programs are provided throughout the year or sometimes the number of participants can be limited due to the fact that not all their premises are heated during cold season.

Researched educational programs are oriented towards organized groups of visitors - groups of pupils, employees of companies, families, etc. Educational programs mostly are organized for citizens of our country. The variety of educational programs oriented towards the tourists from abroad is very small. Educational programs organized in rural areas are rarely included in tourism routes. Sometimes they are presented as the including part of the offered package of tourism services (for example, museum, excursion in the visitor center and education) and the interest of individual foreign tourist is not very big. On the other hand, the supply is limited by the lack of educators, especially of those, who can speak fluently and communicate in foreign language. Interviewed people stated that communication with the assistance of entrepreneurs significantly reduces the quality and attractiveness of educational programs.

The performed research confirmed theoretical statement that the development of tourism creates new relations and opportunities, involves other participants living in rural areas or cities (Figure 2).

The performed research confirmed that the development of educational tourism contributes to the development of rural areas: the popularity of rural community and area increases, a need to restore public places, environment rises naturally. Interviewed persons stated that while implementing educational programs they cooperate with farmers, rural communities, cultural centers, informational tourism centers, educational institutions, libraries, other business enterprises, which provide educational programs with necessary premises, inventory, tools (beeswax, honey, vegetables, cheese and other) that contribute to the popularity and advertisement of educational programs. This cooperation unites local communities, and the attractiveness of rural area increases at the same time.

In conclusion, it can be stated that educational tourism in Lithuanian rural areas is being developed, there is a wide range of suppliers and supply as well. However, the performed research enabled to identify many factors limiting the development of educational tourism in Lithuanian rural areas. It should be noted that it is very complicated to define one main problem. Firstly, the vitality of demand related to educational programs should be taken into account. In most cases, the product/service developed in rural area and based on limited local resources is devoted to tourists, not local inhabitants. Consequently, it is hard to plan the educators' employment, necessary resources and income from this activity. Therefore, the development of these activities is based on limited resources as well as implementation on minimal risk. Respondents of the interview stated that educational programs are booked for the weekends, holidays, during the period before public holidays (for example, Christmas, Easter, Saint John's Eve). A volatile activity causes difficulties in finding educators. Analyses of two cases showed that former educators left the country and went abroad, because they were not able to maintain family from this activity. And it is not easy to find the replacement for them. Therefore, flexible and various ways to solve this problem are found, for instance, the minimal 
number of participants (for example, at least 10 participants) or the total price of educational program (100 Eur) regardless the number of participants. If tools and equipment necessary for the implementation of educational programs can be transported easily (for example, tools/equipment for wool felting, Easter egg dying) educators agree to implement their educational activities in school.

Secondary, due to decreasing number of citizens in rural areas and small towns (emigration to cities or abroad, high mortality) the number of sponsors and people able to organize and implement educational programs decreases as well. In this case, it is not enough to have specific knowledge (how to recognize footprints of wild animals, voices of birds, to knead dough properly, heat the oven). An educator has to know how to communicate with participants of educational program, encourage their interest, ensure the safety of participants, involve all participants in activities, be creative while transferring knowledge and experience. In addition, it is important to 'create, pack and sell' the service properly, evaluate the activity, identify problems and be able to solve them. Entrepreneurial competences (both general and specific) are very important.

Despite the fact that the research showed that there is cooperation among organizations/participants, the problem related to the stability of demand, the lack of entrepreneurial skills in rural areas, predominance of individualism cause difficulties in ensuring long term cooperation. It can be stated that it is an outcome of history of rural areas. After a long period of common wealth and work, a new type of subculture with new values has grown in the rural area; a need for community is not very relevant any more, individualism has taken its place. Various financial instruments promote communities and cooperation; however, this is not a natural process - thus, often it is short and based on certain interests. In order to increase popularity of educational programs, it is suggested including them in tourism routes - providers of educational programs have to communicate more with informational tourism centers (their network is developed throughout Lithuania). This would help to disseminate information more effectively, because tourists search necessary information regarding districts in these centers. The performed research showed that not in all cases communication with potential clients is effective: often the same person is both - an administrator and an educator. It takes a lot of time to order educational program or obtain necessary information about it. As a result, it is recommended to prepare a virtual calendar of educational programs - a client would have an opportunity to see when educational programs are available. In this calendar other relevant information could be provided, for example, it can be offered for one tourist to join the organized group if there is available vacancy and etc. Also, this calendar could be used as a platform for cooperation with informational tourism centers. Business environment is very dynamic. It does not mean that if specific knowledge and skills were useful one year ago, they will be relevant today. Informational technologies develop very fast, the needs and lifestyle of consumers are changing as well. Therefore, development of entrepreneurial competences has to become a constant process responding to changing environment and preserving traditions, values, uniqueness, sustainability related to environment and rural lifestyle.

\section{Conclusions}

1. The main providers of educational tourism services in Lithuanian rural areas are museums, manors, regional parks, rural communities, countryside tourism homesteads. Various educational programs have been offered to the tourists. They can be grouped according to the topics, which are the following: gastronomy, handicrafts, wildlife, history, culture, local festivals and sport.

2. The research identified the following problems of educational tourism development: lack of communication, weak cooperation, vitality of demand, lack of educators' abilities to develop business in changing environment.

3. Educators' learning, training of educators, improvement of marketing, development of partnerships would contribute to solving the identified problems.

\section{References}

1. Atkočiūnienè, V. (2011). Kaimo turizmo, kaip užimtumo multiplikatoriaus, kaimo vietovèse teorinis kontekstas (The Theoretical Aspect of Rural Tourism as a Multiplicator of Employment in Rural Areas). Management theory and studies for rural business and infrastructure development, 5(29), 33-42. (in Lithuanian)

2. Astromskienè, A. (2009). Vadybiniai kaimo turizmo verslo raidos Lietuvoje aspektai (Managerial Aspects of Rural Tourism Business Development in Lithuania). Management theory and studies for rural business and infrastructure development, 19(4), 14-20. (in Lithuanian)

3. Baležentis, A., \& Žuromskaitè, B. (2012). Turizmo vadyba (Tourism Management). Vilnius: Mykolo Romerio universitetas. (in Lithuanian) 
4. Carneiro, M.J., Lima, J., \& Silva, A.L. (2015). Landscape and the rural tourism experience: Identifying key elements, addressing potential, and implications for the future. Journal of Sustainable Tourism, 23(8-9), 1217-1235. DOI: 10.1080/ 09669582.2015.1037840.

5. Hermawan, P., Widiyanti, R., Mayangsari, L., \& Novani, S. (2018). Urban tourism development for Bandung city, Indonesia: a preliminary study. International Journal of Business and Society, 19 (1), 73-86.

6. Kuliešis, G., \& Pareigienè, L. (2014). Demografinių veiksnių poveikis kaimo gyvybingumui (Impact of Demographic Factors to Rural Vitality). Management theory and studies for rural business and infrastructure development, 36 (1), 66-73. (in Lithuanian)

7. Lane, B., \& Kastenholz, E. (2015). Rural tourism: The evolution of practice and research approaches - towards a new generation concept? Journal of Sustainable Tourism, 23 (8-9), 1133-1156. DOI: 10.1080/09669582.2015.1083997.

8. Petroman, C., Mirea, A., Lozici, A., Constantin, E.C., Marin, D., \& Merce, I. (2016). The rural educational tourism at the farm. Procedia Economics and Finance, 39, 88-93. DOI: 10.1016/S2212-5671(16)30245-3.

9. Pilipavičius, V. (2011). Bendruomeninio verslumo formavimas ir kaimo vietovių konkurencingumo stiprinimas (Formation of Community Entrepreneurship and Increasing Competitiveness of Rural Areas). Ekonomika ir vadyba: aktualijos ir perspektyvos, 4(24), 169-178. (in Lithuanian)

10. Richards, G., \& Wilson, J.E. (2007). Tourism, creativity and development. New York: Routledge, pp. 346.

11. Sie, L., Patterson, I., \& Pegg, S. (2016). Towards an understanding of older adult educational tourism through the development of a three-phase integrated framework. Current Issues in Tourism, 19 (2), 100136.

12. Wang, L., \& Yotsumoto, Y. (2018). Conflict in tourism development in rural China. Tourism Management, 70, 188-200.

13. Zaleckienè, J. (2015). Ūkininko ūkio diversifikacijos sprendimo prièmimas (Farmer's Farm Diversification Decision Making). Doctoral dissertation, Aleksandras Stulginskis University, Akademija. (in Lithuanian) 